\title{
Collaborative Design Studio on Trial: A Conceptual Framework in Practice
}

\author{
Hesam Kamalipour1,2, Zahra Mansouri Kermani2,3, Elaheh Houshmandipanah ${ }^{2,3}$ \\ ${ }^{1}$ Department of Architecture, School of Architecture and Environmental Design, Iran University of \\ Science and Technology, Tehran, Iran \\ ${ }^{2}$ Department of Architecture, Saba Faculty of Art and Architecture, Shahid Bahonar University \\ of Kerman, Kerman, Iran \\ ${ }^{3}$ Young Researchers Society, Shahid Bahonar University of Kerman, Kerman, Iran \\ Email: hkamalipour@iust.ac.ir
}

Received 5 January 2014; revised 25 January 2014; accepted 20 February 2014

Copyright (C) 2014 by authors and Scientific Research Publishing Inc.

This work is licensed under the Creative Commons Attribution International License (CC BY). http://creativecommons.org/licenses/by/4.0/

(c) (i) Open Access

\section{Abstract}

Addressing interactive and communicative aspects of design process, architectural pedagogy, and practices of urban education, collaborative design studio (CDS) has become a considerable area of interdisciplinary research in the past years. However, a growing body of knowledge in CDS studies shows that the criteria of evidence-based practices, empirical explorations, and theoretical conceptualization of CDS have not been addressed properly yet. Thus, adopting quantitative and qualitative approaches, the study tends to provide a conceptual framework for CDS studies and explore the interrelations between three parameters of the generated model through a case study of collaborative design studio in practice. Firstly, the study tends to conceptualize various dimensions of collaborative design studio based on the previous researches in terms of place, content, process, time, and size. Secondly, the study implements correlational research methods in terms of structural equation model (SEM) and factor analysis in order to explore interrelations between parameters of size, place, and process in a case study. In this way, findings of the study indicate that the parameter of size has significant influences on the process factor in CDS practices. Moreover, it suggests that the parameter of place is not likely to have considerable impact on the factor of process.

\section{Keywords}

Collaborative Design Studio; Urban Education; Design Process; Architectural Pedagogy; Urban Housing Studio 


\section{Introduction}

Design studios in the context of architecture, urban design, and planning education are the settings of debate, creativity, discussion, imagination, critique, consult, challenge, improvement, contest, and collaboration. A review of literature on design process and urban education in design studios indicates a focus on personal ways of thinking and designing practices either in academic context or experiences of professional practices. Meanwhile, experiences of design studios in the faculties of architecture, design, and planning reveal a common dominance of individuality and personal-biased tendencies in design practices regardless of whether it has been encouraged by academics/milieu of the school or personal/individual preferences. However, while most of the students in architecture, urban design, and planning tend to pursue their projects and design practices personally in isolation from others, it is critically a tendency to learn and improve through debate, challenge, and discussion with others in design studio. Actually, there is an extensive body of knowledge on the issue of design process and education (Lawson, 2004, 2006), which refers to the complexity of design problems and does not simply propose a linear universally accepted process as a "recipe" for the solution of design problems. Having this in mind, one might suppose that design studios are the actual settings for the complex intersections of individual design processes, diverse personal ways of thinking, and normative manifestations, theories, and practices. In this way, the issue of "collaboration" has become considerably popular in recent years (McPeek, 2009) and students from different disciplines have been relatively involved in collaborative activities and practices (Alpay \& Littleton, 2001; Crosbie, 1995; Denton, 1997; Gabriel \& Maher, 2002; Schmitt, 1998). In fact, architects need interaction with others who can affect and complement them (Martin, Fruchter, Cavallin, \& Heylighen, 2007). Thus, students communicate, interact, and discuss in design studios with their peers and other academics and professionals. Moreover, previous researches have provided evidences that design process will improve effectively as a result of communication, but the skill of communication does not often come easily (Daniel, 2002). In this way, collaborative pedagogy is a critical part of design education in architecture, urban design, and planning that can be held in the actual setting of a design studio. In order to provide more empirical evidences and explore different dimensions of collaborative design studio in practice, the paper addresses the relations between process, place, and size through implementation of a collaborative design studio in a case study practice.

\section{Design Studio, Collaboration, and Urban Education}

Reviewing the related literature on design studio within the broad context of design pedagogy and architectural education, one might suppose that design studio is not only a particular form of education (Schön, 1985), but also the "core" of architectural education (Gross \& Do, 1997; Kuhn, 2001; Ochsner, 2000; Webster, 2004), which concentrates on learning by doing (Ismail \& Soliman, 2010; Kurt, 2009; Schön, 1985, 1988). It provides an environment for collaborative, learner-centered, experiential problem-based teaching (Kurt, 2009) through social interactions between teacher(s) and students and among students (Colbeck \& Campbell, 2000; Demirbas \& Demirkan, 2003; Gross \& Do, 1997; Ismail \& Soliman, 2010; Ochsner, 2000; Pringle, 2009; Schön, 1984). In this pedagogical model, students meet several numbers of the week and engage with the faculty member(s) and their peers while they are all working in a group (Bronet, 2000). In fact, design studio is an active mode of learning where students solve problems and projects through a process (Strong \& Stiver, 2005) that is known as a "dialogue of thinking and doing" (Schon, 1995) in which participants tend to improve their abilities and skills (Pektas, 2012). Through this open interaction (Sagun \& Demirkan, 2009), members become aware of their social role in design process and learn about a broad network of participants (Kvan, 2001; Vyas, Heylen, Nijholt, \& Van Der Veer, 2009). However, it is a possibility that students may entirely consider themselves as individuals, not as a member of their group. Regarding theoretical approaches, practical attributes, and research areas in design process discourse, design pedagogy primarily focuses on the practical aspects rather than theory or research (Gray, 2011). Meanwhile, it is actually noteworthy to mention that design process, as an educational subject, is characterized by the lack of clear separation between practical skills and theoretical knowledge (Simoff \& Maher, 2000). In this way, the common ground of interactions between design studio, collaboration, and architectural education covers the intersection of practical aspects of design, empirical evidences, and experiences in the context of design studio.

Moreover, different scholars have addressed impacts of collaborative experiences on the process, outcome, and feedback of educational practices in design studios. For example, Bronzino, Ahlgren, Chung, Mertens, and Palladino (1994) outline that in a collaborative teamwork, the participants communicate with their peers to ac- 
complish their duty, tackle social complications and problems, and improve their self-confidence. Moreover, cooperative learning is relatively stronger than the old methods of pedagogy since it stimulates students for devoting more activity and participation to the learning process (Astin, 1993; Pierre Dillenbourg, Baker, Blaye, \& O’Malley, 1996). In fact, collaborative teamwork is crucial as an operative practice rather than just being a choice (McCallin \& McCallin, 2009; Yin, Qin, \& Holland, 2011). In this way, collaboration is about a group who work together to fulfill a common goal (Chiu, 2002; Macpherson, 2008; J. C. Tang, 1991). However, it seems that some collaborative skills are required in order to achieve the common goal. Hence, Bosworth (1994) classifies these skills in five main categories including interpersonal skills, inquiry skills, group building management, conflict, and presentation. Similarly, Détienne, Boujut, and Hohmann (2004) add “cognitive synchronization" to these categories and emphasize on "proposing and enhancing solutions". However, collaborative skills can be considered as the activities in which a possible weakness in any of the items is likely to cause difficulties in process of the project.

Regarding the possible impacts of collaborative design, a considerable body of knowledge indicates that collaborative design involves participants that each of them solves a part of design issues or analyzes the possible solutions from his/her perspective (Belkadi, Bonjour, Camargo, Troussier, \& Eynard, 2013; Pierre Dillenbourg et al., 1996; Klein, Sayama, Faratin, \& Bar-Yam, 2006; Ochsner, 2000). Thus, aims of collaborative design are generally innovation of members (Gray, 2011) and creativity (Crilly, 2010; Fleck, 1981; Lewis, 2006; Logan, 2008; Soliman \& Okba, 2006) through sharing ideas, expertise or responsibilities. However, each project in collaborative design has allocated goals and individuals should do various tasks and acquire diverse design information in order to communicate, solve design problems, and achieve the specified goals (Chiu, 2002; Kuhn, 2001). Taking place in the context of design process (Blevis, 2010), the critique discussion is the main communicative feature of the studio through which the students learn to critique, respond, and collaborate (Gross \& Do, 1997; Russ \& Dickinson, 1999). Thus, In order to have an effective cooperation, one needs to know about the other participants in terms of their information, background, and expectations (Carroll, Neale, Isenhour, Rosson, \& McCrickard, 2003). Moreover, it is necessary to have adequate information about the working situation/condition while making individual plans through the projects_(Belkadi et al., 2013). However, it is necessary to provide collaborative approaches and methods with more empirical experiences that are likely to be justified and grounded in the context of design studios in architectural education and design pedagogy. In this way, the paper tends to argue about the implementation of collaborative design studio in a case study

\section{Collaborative Design Studio: A Conceptual Framework}

According to the case study and previous researches, the study suggests a conceptual model as a possible framework for adopting a relatively comprehensive approach to conceptualize the attributes of collaborative design studio in order to provide empirical case studies in practice. Thus, previous studies and the case study suggest that implementation of collaborative design studio in practical experiences is related to the factors of process, content, time, place, and size (Table 1). Hence, the studies that referred to the criteria of process outline social interaction, participation in the learning process, problem solving, innovation and creativity, competition, individuality, learning by doing, sharing ideas, work distribution, comparison to individual work, communication problems, evaluation, and critique (Table 1). Moreover, the issue of content refers to subject of the design studio in relation to improvement of individuals through collaborative experience while the factor of size denotes the quantity of instructors in relation to participants of collaborative design studio (Table 1). Furthermore, the studies that referred to the issue of place mainly concern with the insufficient space, environmental limitation, and the physical setting of design studio (Table 1). Finally, the factor of time concentrates mostly on time limitations and differences between various cases (Table 1).

In this way, the study suggests a conceptual framework for exploring collaborative design studio in relation to place, process, time, content, and size in order to conceptualize various dimensions of implementing collaborative design studio in practices of architectural education (Figure 1). However, there is not an equitable and same body of knowledge for each dimension of process, place, content, time, and size. Hence, the process factor has been largely explored in the past researches (Table 1). Conversely, the parameters of size, time, place, and content have been less discussed in practices of CDS in comparison to process factor. Moreover, the study of interrelations between these factors has not been conducted in practical implementations of collaborative design studio in different case studies. Meanwhile, since the number of cases is a critical issue in quantitative analysis 
Table 1. Dimensions, focuses, and concerns in various studies of the collaborative design studio (Source: Authors).

\section{Social interaction}

(Schön, 1984) (Bronzino et al., 1994) (Pierre Dillenbourg et al., 1996) (Gross \& Do, 1997) (Bronet, 2000) (Colbeck \& Campbell, 2000) (Ochsner, 2000) (Kvan, 2001) (Valkenburg, 2001) (Chiu, Yamaguchi, \& Morozumi, 2001) (Demirbas \& Demirkan, 2003) (Carroll et al., 2003) (Romice \& Uzzell, 2005) (Tucker \& Reynolds, 2006) (Martin et al., 2007) (Peeters, van Tuijl, Reymen, \& Rutte, 2007) (H.-H. Tang \& Lee, 2008) (Macpherson, 2008) (Vyas et al., 2009) (McPeek, 2009) (Schnabel, 2009) (Pringle, 2009) (Kurt, 2009) (Sagun \& Demirkan, 2009) (Ismail \& Soliman, 2010) (Blevis, 2010) (Pektas, 2012)

\section{Participation and Competition}

(Astin, 1993) (Pierre Dillenbourg et al., 1996) (Kurt, 2009) (Ismail \& Soliman, 2010) (Blevis, 2010) (Hassanain, Mohammed, \& Cetin, 2012)

\section{Problem solving}

(J. C. Tang, 1991) (Blumenfeld et al., 1991) (Schon, 1995) (Pierre Dillenbourg et al., 1996) (Kvan, 2000) (Ochsner, 2000) (Kuhn, 2001) (Chiu, 2002) (Strong \& Stiver, 2005) (Klein et al., 2006) (Logan, 2008) (Kleinsmann \& Valkenburg, 2008) (Sagun \& Demirkan, 2009) (Kurt, 2009) (Ismail \& Soliman, 2010) (Pektas, 2012) (Belkadi et al., 2013)

\section{Innovation and Creativity}

(Slavin, 1995) (Colbeck \& Campbell, 2000) (Engeström, 2001) (Valkenburg, 2001) (Lewis, 2006) (Soliman \& Okba, 2006) (Logan, 2008) (Ungar \& White, 2008) (Vyas et al., 2009) (Crilly, 2010) (Gray, 2011) (Hassanain et al., 2012)

\section{Individuality}

(Mello, 1993) (Crosbie, 1995) (Pierre Dillenbourg et al., 1996) (Ehrlenspiel, Giapoulis, \& Günther, 1997) (Martin et al., 2007) (Hellström, 2007) (Kamalipour, Houshmandipanah, \& Mansouri Kermani, 2013)

Process

\section{Learning by doing}

(Schön, 1984) (Schön, 1985) (Schön, 1988) (Kurt, 2009) (Yilmaz, Seifert, \& Gonzalez, 2010) (Ismail \& Soliman, 2010)

\section{Sharing ideas}

(Blumenfeld et al., 1991) (Gross \& Do, 1997) (Kvan, 2000) (Chiu, 2002) (Gabriel \& Maher, 2002) (Demirbas \& Demirkan, 2003) (Summers, Gorin, Beretvas, \& Svinicki, 2005) (Larsson, Törlind, Bergström, Löfstrand, \& Karlsson, 2005) (Romice \& Uzzell, 2005) (Ungar \& White, 2008) (Sagun \& Demirkan, 2009) (Ismail \& Soliman, 2010) (Wang, Shih, \& Chien, 2010) (Arefi \& Edelman, 2013)

\begin{tabular}{l} 
Work distribution \\
\hline (Bosworth, 1994) (Chiu, 2002) (Cheng, 2003) (Summers et al., 2005) (Tseng, Tzeng, \& Lin, 2005) (Romice \& Uzzell, 2005)
\end{tabular}

(Bosworth, 1994) (Chiu, 2002) (Cheng, 2003) (Summers to individual work
Comparison

(Millis \& Cottell, 1998) (Gatfield, 1999) (Tucker \& Reynolds, 2006) (Ungar \& White, 2008)

\section{Communication problems}

(Mello, 1993) (Crosbie, 1995) (Ehrlenspiel et al., 1997) (Ochsner, 2000) (Martin et al., 2007) (Kleinsmann, Buijs, \& Valkenburg, 2010) (Gray, 2011) (Kamalipour et al., 2013)

\section{Evaluating and Critique}

(Pierre Dillenbourg et al., 1996) (Gross \& Do, 1997) (Gross and Do 1997) (Russ and Dickinson 1999) (Bowring, 2000) (Lewis, 2006) (Logan, 2008) (Macpherson, 2008) (Ungar \& White, 2008) (McPeek, 2009) (Blevis, 2010) (Gray, 2011) (Oh, Ishizaki, Gross, \& Yi-Luen Do, 2012)

\section{Improvement of individuals}

Content (Fleck, 1981) (Mello, 1993) (Kvan, 2001) (Romice \& Uzzell, 2005) (Martin et al., 2007) (Ungar \& White, 2008) (Vyas et al., 2009) (Yilmaz et al., 2010) (Pektas, 2012) (Hassanain et al., 2012) (Kamalipour \& Biglari, 2013)

\section{Design studio}

(D. Schön 1985) (Schön, 1988) (Schon, 1995) (Gross \& Do, 1997) (Bronet, 2000) (Kuhn, 2001) (Demirbas \& Demirkan, 2003) (Duggan, 2004) (Larsson et al., 2005) (Ungar \& White, 2008) (Vyas et al., 2009) (McPeek, 2009) (Yilmaz et al., 2010) (Strong \& Stiver, 2005) (Hassanain et al., 2012) (Oh et al., 2012) (Belkadi et al., 2013)

Place

\section{Environmental limitations}

(Boling \& Smith, 2010) (Gray, 2011) (Kamalipour et al., 2013)

Insufficient Space

(Reimer \& Douglas, 2003) (Wang et al., 2010)

\section{Differences in cases}

Time

(Schmitt, 1998) (Bronet, 2000) (Strong \& Stiver, 2005)

$$
\text { Time limitations }
$$

(Ungar \& White, 2008) (Boling \& Smith, 2010)

Size

(Ochsner, 2000)

Instructor(s) 


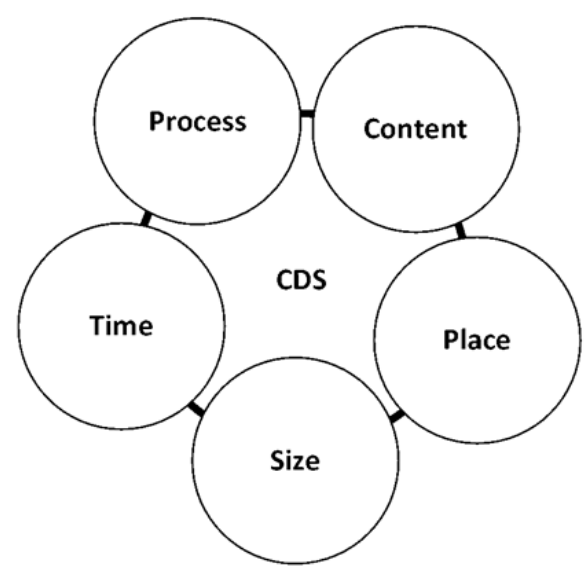

Figure 1. A Conceptual Framework for Collaborative Design Studio (Source: Authors).

through structural equation modeling, it is not feasible to analyze the overall conceptual model and all the interactions between parameters of process, place, time, size, and content with limited number of cases. In this way, since most of participants have referred explicitly to factors of place and size, the study tends to explore the influences of size and place on process factor. Thus, the assessment of interrelations between all the affecting factors in relation to CDS is out of the scope of this paper. Moreover, since time and content are relatively different in various cases, this study explores the relations between process, place, and size through a practical implementation of collaborative design studio in architectural education in order to contribute empirical evidences along with provision of a conceptual model for multi-dimensional study of the CDS in practice.

\section{Research Methods}

Adopting quantitative and qualitative approaches, the study explores the growing body of knowledge in the intersection area of study in design process, architectural education, and collaborative design studio in order to conceptualize various dimensions of collaborative design studio in a relatively comprehensive framework for the case study. Moreover, implementing a quantitative approach in a case study of urban housing studio at Shahid Bahonar University of Kerman in Iran, the study adopts correlational research methods in terms of SEM and factor analysis in order to explore the relations between size, place, and process in the case study. The content of collaborative studio in the case study was about analyzing and designing urban housing in a part of a recently developed residential district along with provision of mixed land uses in terms of cultural, educational, recreational, commercial facilities, open green space, and shop houses in order to meet dwellers needs and desires within the context of the city. Each student had two individual housing projects and every 3 - 4 students were asked to constitute a sub group for their presentations and design of the mixed land uses and facilities. Moreover, the main collaborative group included all participants (14 students) for the site planning, analysis of the urban fabric, and making of the study model for the studio in order to simulate urban fabric of the district. Meanwhile, all of the participants were the second-year students of architecture in undergraduate program and the whole case study took approximately between seven to eight months.

A structured questionnaire has been designed in order to measure process, content, time, size, and place. After a pilot study in the same context, the questionnaire has been revised in order to measure size, place, and process because of the numerical limitation of the participants who have actually experienced a collaborative design studio in the case study (Figure 2). Thus, the questionnaire has been adopted for measuring size through three items, place through four items, and process through nine items (Table 2). Moreover, based on their actual experience of a collaborative design studio in the case study, the students were asked to evaluate each item within a 5-Likert scale from (1) poor to (5) excellent. The program of collaborative design studio has been implemented in two semesters with different students, 14 students in each semester. After the second semester, 28 students were asked to fill out the questionnaire. Meanwhile, the participants consist of $41 \%$ Males and $59 \%$ Females. However, one of the participants could not fill out and submit the questionnaire.

According to Kline (2011), at least ten cases are necessary for each parameter. In this study, 27 undergraduate 


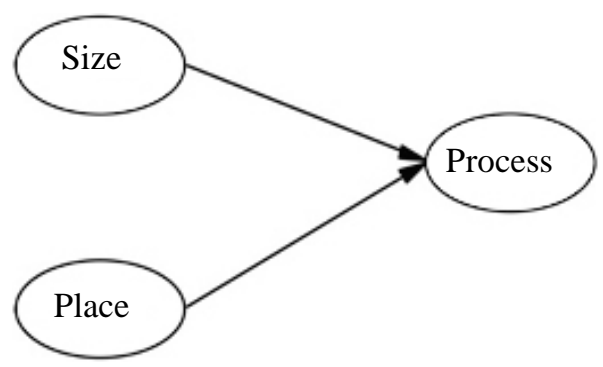

Figure 2. Hypothesized links between factors of place, size, and process for structural equation modeling (Source: Authors).

Table 2. Dimensions and items of the structured questionnaire in the case study (Source: Authors).

\begin{tabular}{l}
\hline The proportion of the main group size for collaborative work (14 members) \\
The proportion of sub groups for collaborative work (2 - 4 members) \\
The proportion of instructor(s) to students in CDS (14 students to 1 instructor) \\
Accessibility to the studio in any time \\
Availability of educational facilities \\
Appropriate physical area for collaborative work \\
Having a specific place arranged for collaborative work \\
The individuals' use from other members' feedback and critics for improving their works \\
Achieving innovative solutions for solving issues in interaction with others \\
Achieving a common goal for collaborative work \\
The generation of social interactions in the main group \\
The generation of social interactions in sub groups \\
Initiating motivation for study, research and competition in CDS \\
Being aware of the collaborative work attributes and conditions (before the beginning of CDS) \\
Appropriateness of the semester schedule (4 months) for CDS \\
Appropriateness of the weekly schedule for CDS implementation
\end{tabular}

students, who had previously participated in the proposed program of collaborative design studio in their urban housing studio, filled out the structured questionnaire after their experience of the collaborative design studio. Thus, a sum of 27 complete questionnaires have been analyzed using SPSS for descriptive statistics and LISREL for confirmatory factor analysis (CFA) and structural equation model (SEM) in order to explore the relations of place and size to process in collaborative design studio. Using Cronbach's alpha as "an index of reliability" (Santos, 1999), the analysis indicates an overall Cronbach's alpha of .75 for items of the questionnaire which reveals an acceptable reliability. Meanwhile, using chi-square/degree of freedom and RMSEA, the study analyses the model goodness of fit. A chi-square/degree of freedom relation of 3:1 or less is acceptable (Carmines \& McIver, 1981) while an RMSEA less than .06 is recommended (Hu \& Bentler, 1999) for analyzing the model goodness of fit. Moreover, the cut-off value of .30 is acceptable for the study of factor loading in the study (Sellin \& Keeves, 1997). However, $t$-value analysis is also applied for the assessment of strength of the relations between the factors of size, place, and process in structural equation modeling in the case study. Vieira (2011) recommends that $t$-value is better to be greater than 1.96 for the analysis of directions and strength of hypothesized links.

\section{Results and Discussion}

Results of the study indicate that students were relatively pleased with the factor of size in terms of the proportion of the main group size (55\%), the sub groups (85\%), and the number of instructor(s) (55\%). However, the faculty has specified the proportion of the main group size (14 students) and it was not changeable in each se- 
mester. Meanwhile, the maximum number of members in sub groups was four. As a result, appropriate cooperation and interaction has been generated between the participants in relation to the overall intensity of the collaborative project. Furthermore, the results show that it was possible for one main instructor to manage and conduct the collaborative design studio, so there was no need for presence of more instructors in the case study. Regarding the questionnaire item that are related to process parameter, there was a considerable result that indicates most of the students (63\%) agreed with the high social interaction in sub groups. However, since the participants decided about their partners and roles in design process, sub groups were more successful in comparison to the main collaborative group in which the students had not the choice of selecting their peers prior to the commencement of the collaborative studio. Furthermore, regarding the place factor, a great number of the participants (52\%) denoted that they did not have access to the collaborative studio on a daily basis because there were other design studios scheduled in the same physical setting in different days. Moreover, the physical attributes of the collaborative studio did not offer participants an adequate area for collaborative work. Similarly, the students noted the lack of a permanent and fulltime allocated location for the collaborative design during the semester.

Implementing chi-square/degree of freedom and RMSEA, the analysis of the model goodness of fit indicates that the model has a reasonable goodness of fit in terms of chi-square/degree $(122.30 / 101<3: 1)$, but it shows only a relatively goodness of fit in terms of RMSEA analysis $(.090>.06)$. The structural model indicates that the two last items referred to the issue of timing schedules for measuring the process factor could not acquire an acceptable loading factor $(.22<.3$ and $.07<.3)$ while the fifth item of the place parameter is relatively in the threshold of acceptance $(.28<.3)$ (Figure 3). Moreover, the findings show that the loading factor of the third item for the measurement of the size factor is not acceptable either $(.16<.3)$ (Figure 3). However, all of the other items could acquire a reasonable loading factor in the structural model. Furthermore, $t$-value analysis between the factors of place and process does not imply a significant $(1.41<1.96)$ relation between place and process factors in terms of strength and direction of the influence in structural equation modeling of the case study. Meanwhile, $t$-value analysis between the size and process factors indicates a significant $(2.67>1.96)$ relation in the hypothesized structural equation modeling.

The outcome of the case study indicates that the parameter of place does not have a significant influence on process (loading factor: .28). However, the findings show that the students did not pursue the collaborative work

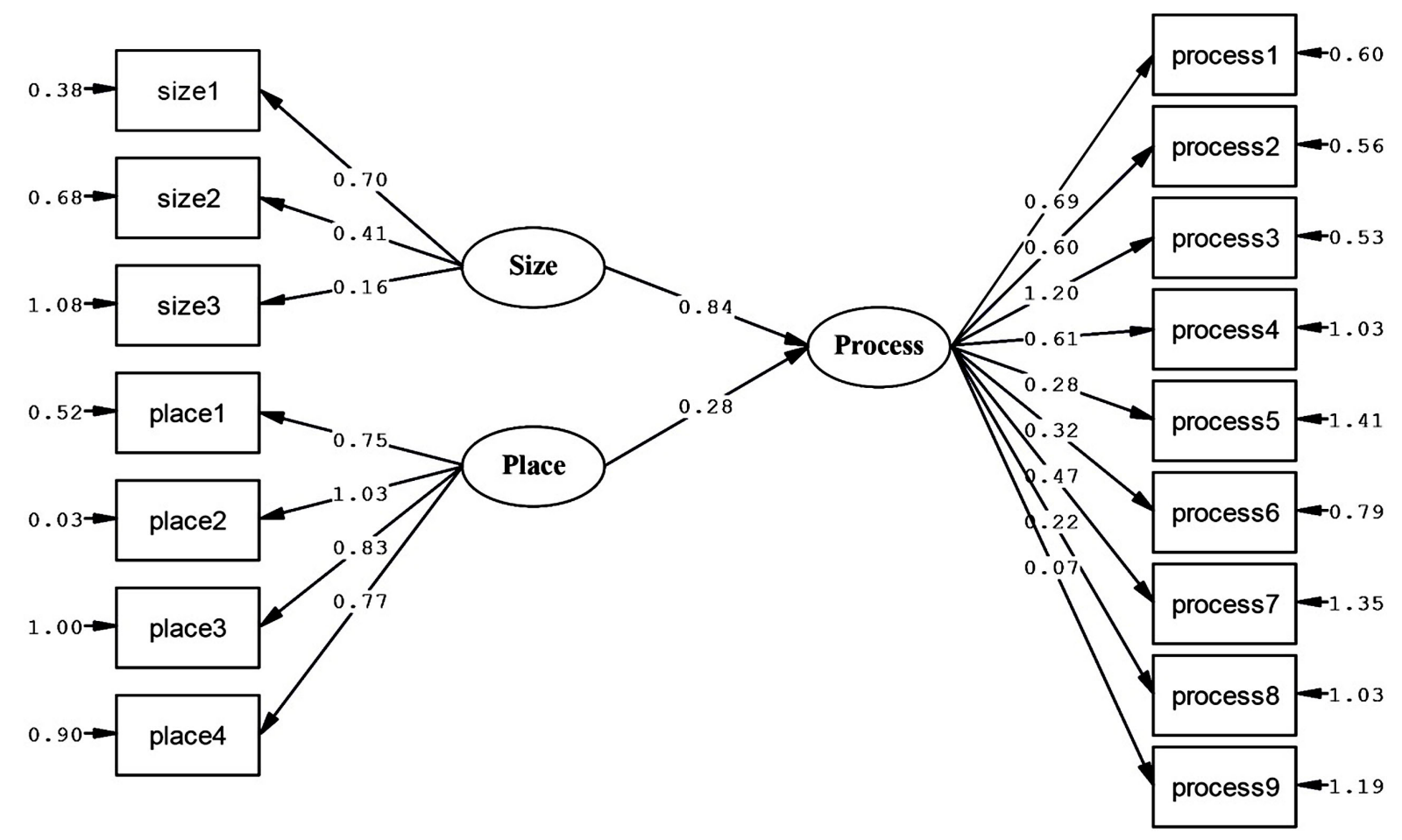

Figure 3. A structural model with three parameters of size, place, and process (Source: Authors). 
in a steady rhythm and the quantity of the participants has gradually decreased at the end of the semester in their affiliated groups. Moreover, in some points of the practical experience, although there was a relatively adequate and allocated area for the collaborative design studio, not all of the students were present for pursuing their collaborative work within the main or sub groups. On the other hand, as Bento (1997) argues, the morale and productivity tends to increase in the last stages of a teamwork. Similarly, the number of active participants again increased within the last month of the case study. Thus, it is relatively reasonable that why the lack of a fixed location with appropriate area and space might not be a considerable limitation that can influence the process and performance of a collaborative design studio. However, In spite of the place limitations for accommodating the collaborative design studio, the participant could efficiently discuss their ideas, criticize, interact, and generate creative design solutions in the process of education.

Since most of the participants did not have a prior introduction to the collaborative design studio in terms of common goals, responsibilities, timing, and intensity of work, they could not (or relatively could) efficiently manage their adaptation and resilience for the whole process of the collaborative design studio. In this way, although members of the sub/main group could interact and contribute to the process of idea sharing, critiques, and problem solving, the absence of mutual reliance and trust between students might lead to individual considerations in the process of task accomplishment rather than collaborative thinking. Consequently, most of the students preferred to do their works individually at home instead of the collaborative studio. In this way, it might be redundant to provide a fulltime studio with exclusively allocated facilities for the mere purpose of a collaborative design studio. However, since most of the previous studies did not take into account the parameter of place for the study of collaborative design studio, the results of this study does not propose a significant relation between place parameter and process factor.

As it has been outlined before, actually a few studies have considered a relation between process and place and these studies are different from this study mainly in terms of methodology and research design. For example, within an eight-month study, Vyas et al. (2009) referred to the spatial setting as one of the three major themes of collaborative studio. The study explored two industrial design departments. In addition to observations, they used video record of the sessions, and interviews of ten master students in industrial design and five designers/design researchers. Another study in Saudi Arabia (Hassanain et al., 2012) was conducted with twenty six students of architecture from different years. The study applied inspection, question survey, and interviews. Meanwhile, they interviews fifteen participants and four instructors. The study referred to background environment and functional requirements of place in order to have a productive and efficient collaborative design studio in practice. However, their major finding in suggesting the place parameter as a dimension of collaborative design studio is in consistency with the findings of this study.

Furthermore, findings of the case study indicate that size factor has a significant influence on the process parameter (loading factor: .84). Although the results of the analysis show a significant influence, but the literature review does not specifically discuss the relation between neither these two parameters, nor the factor of size itself. Exceptionally, a few studies address the issue of size as one of the collaborative design dimensions. For example, Ochsner (2000) denoted that the students-instructor ratio should be managed to be relatively around 13:1 or 14:1. Thus, in the case study of urban housing studio, the participants were relatively satisfied with the same proportion, which was fourteen (students) to one (instructor). Regarding the critical role of the size parameter, the recent studies have paid little attention to the issue of size factor as a dimension of collaborative design studio in comparison to the parameter of place.

Meanwhile, the results of the case study indicate that there is a difference between the responses of the main and sub groups to the factor of size. Thus, as the size of a group increases, the social interactions between the group members decrease. In this way, the participants preferred to discuss, cooperate, and interact relatively more in smaller group size (sub groups) than the larger group size (main group). However, there is another issue here in relation to the size of the main and sub groups. Since the students were not able to choose their peers in the main group, they might have become relatively reluctant to establish social interactions in the main group. Conversely, the participants had the opportunity of selecting their peers in sub groups. Thus, it seems to be a considerable issue for justifying the differences responses between sub and main groups to the parameter of size in collaborative design studio.

Finally, it is actually noteworthy to note that the study has some limitations in terms of the case study, timing, intensity of the content, and number of participants. In the case of number of participants, who have contributed to the final evaluation and questionnaire, the number of cases could be more than 27 in order to provide more rigor assessment and judgment based on the structural equation model in which the number of cases is critical. 
In fact, the study could not practically explore the influence of the proposed conceptual framework due to the limitation of the number of cases. Hence, it is relatively unlikely to generalize the outcome of the study because of the limitation of participants and cases. However, the study suggests the exploration of the relations between the other proposed dimensions of CDS in different case studies. Moreover, the participants of the case study faced with some deficiencies in terms of an adequate physical space, timing limitations, and intensity of the content that might have intervene with their final assessment and evaluation of the related factors.

\section{References}

Alpay, L. L., \& Littleton, K. S. (2001). Contexts for Collaboration in Healthcare Education. Health Informatics Journal, 7 , 121-126. http://dx.doi.org/10.1177/146045820100700302

Arefi, M., \& Edelman, D. J. (2013). Morrow Tomorrow: Exploring the Pedagogical Experience of a Planning Studio Involving Students with Mixed Skills. Current Urban Studies, 1, 59. http://dx.doi.org/10.4236/cus.2013.13007

Astin, A. W. (1993). What Matters in College? Four Critical Years Revisited. San Francisco: Jossey-Bass.

Belkadi, F., Bonjour, E., Camargo, M., Troussier, N., \& Eynard, B. (2013). A Situation Model to Support Awareness in Collaborative Design. International Journal of Human-Computer Studies, 71, 110-129. http://dx.doi.org/10.1016/j.ijhcs.2012.03.002

Bento, R. F. (1997). Creating the Conditions for Successful Teamwork in College Courses: A Systems Approach to Teamwork Design Decisions. College Student Journal, 31, 137-144.

Blevis, E. (2010). Design Challenge Based Learning (DCBL) and Sustainable Pedagogical Practice. Interactions, $17,64-69$. http://dx.doi.org/10.1145/1744161.1744176

Blumenfeld, P. C., Soloway, E., Marx, R. W., Krajcik, J. S., Guzdial, M., \& Palincsar, A. (1991). Motivating Project-Based Learning: Sustaining the Doing, Supporting the Learning. Educational Psychologist, 26, 369-398. http://dx.doi.org/10.1080/00461520.1991.9653139

Boling, E., \& Smith, K. M. (2010). Intensive Studio Experience in a Non-Studio Masters Program: Student Activities and Thinking across Levels of Design. Montreal, CA: Paper Presented at the Design Research Society.

Bosworth, K. (1994). Developing Collaborative Skills in College Students. New Directions for Teaching and Learning, 1994, 25-31. http://dx.doi.org/10.1002/tl.37219945905

Bowring, J. (2000). Increasing the Critical Mass: Emphasising Critique in Studio Teaching. Landscape Review, 6, 41-52.

Bronet, F. (2000). Quilting Space. Knowledge and Society, 12, 229-261.

Bronzino, J. D., Ahlgren, D. J., Chung, C.-L., Mertens, J. D., \& Palladino, J. L. (1994). Design and Teamwork: A Must for Freshmen. IEEE Transactions on Education, 37, 184-188. http://dx.doi.org/10.1109/13.284992

Carmines, E. G., \& McIver, J. P. (1981). Analyzing Models with Unobserved Variables: Analysis of Covariance Structures. In G. W. Bohrnstedt, \& E. F. Borgatta (Eds.), Social Measurement: Current Issues (pp. 65-115). Beverly Hills: Sage Publications, Inc.

Carroll, J. M., Neale, D. C., Isenhour, P. L., Rosson, M. B., \& McCrickard, D. S. (2003). Notification and Awareness: Synchronizing Task-Oriented Collaborative Activity. International Journal of Human-Computer Studies, 58, 605-632. http://dx.doi.org/10.1016/S1071-5819(03)00024-7

Cheng, N. Y.-W. (2003). Approaches to Design Collaboration Research. Automation in Construction, 12, 715-723. http://dx.doi.org/10.1016/S0926-5805(03)00059-1

Chiu, M.-L. (2002). An Organizational View of Design Communication in Design Collaboration. Design Studies, 23, 187210. http://dx.doi.org/10.1016/S0142-694X(01)00019-9

Chiu, M.-L., Yamaguchi, S., \& Morozumi, M. (2001). Supporting Collaborative Design Studios—Scenarios and Tools. Computer-Aided Architectural Design Research in Asia (CAADRIA), 125-134.

Colbeck, C. L., \& Campbell, S. E. (2000). Grouping in the Dark: What College Students Learn from Group Projects. Journal of Higher Education, 71, 60-83. http://dx.doi.org/10.2307/2649282

Crilly, N. (2010). The Structure of Design Revolutions: Kuhnian Paradigm Shifts in Creative Problem Solving. Design Issues, 26, 54-66. http://dx.doi.org/10.1162/desi.2010.26.1.54

Crosbie, M. J. (1995). The Schools: How They're Failing the Profession (and What We Can Do about It). Progressive Architecture, 76, 47-51.

Daniel, R. W. (2002). Reinventing Ourselves: Interdisciplinary Education, Collaborative Learning, and Experimentation in Higher Education (Review). The Journal of Higher Education, 73, 667-669. http://dx.doi.org/10.1353/jhe.2002.0044

Demirbas, O. O., \& Demirkan, H. (2003). Focus on Architectural Design Process through Learning Styles. Design Studies, 24, 437-456. http://dx.doi.org/10.1016/S0142-694X(03)00013-9 
Denton, H. G. (1997). Multidisciplinary Team-Based Project Work: Planning Factors. Design Studies, 18, 155-170. http://dx.doi.org/10.1016/S0142-694X(97)85458-0

Détienne, F., Boujut, J.-F., \& Hohmann, B. (2004). Characterization of Collaborative Design and Interaction Management Activities in a Distant Engineering Design Situation. Amsterdam: IOS Press.

Dillenbourg, P., Baker, M. J., Blaye, A., \& O’Malley, C. (1996). The Evolution of Research on Collaborative Learning. In E. Spada, \& P. Reiman (Eds.), Learning in Humans and Machine: Towards an Interdisciplinary Learning Science (pp. 189-211). Oxford, UK; New York: Pergamon.

Duggan, F. (2004). The Changing Nature of the Studio as an Educational Setting. Transactions, 1, 70-76. http://dx.doi.org/10.11120/tran.2004.01020070

Ehrlenspiel, K., Giapoulis, A., \& Günther, J. (1997). Teamwork and Design Methodology-Observations about Teamwork in Design Education. Research in Engineering Design, 9, 61-69. http://dx.doi.org/10.1007/BF01596482

Engeström, Y. (2001). Expansive Learning at Work: Toward an Activity Theoretical Reconceptualization. Journal of Education and Work, 14, 133-156. http://dx.doi.org/10.1080/13639080020028747

Fleck, L. (1981). Genesis and Development of a Scientific Fact. Chicago: University of Chicago Press.

Gabriel, G. C., \& Maher, M. L. (2002). Coding and Modelling Communication in Architectural Collaborative Design. Automation in Construction, 11, 199-211. http://dx.doi.org/10.1016/S0926-5805(00)00098-4

Gatfield, T. (1999). Examining Student Satisfaction with Group Projects and Peer Assessment. Assessment \& Evaluation in Higher Education, 24, 365-377. http://dx.doi.org/10.1080/0260293990240401

Gray, C. M. (2011). Design Pedagogy in Practice: Barriers to Learning and Evaluation in the Design Studio. Department of Instructional Systems Technology, School of Education, Indiana University Bloomington.

Gross, M. D., \& Do, E. Y.-L. (1997). The Design Studio Approach: Learning Design in Architecture Education. Atlanta: Paper presented at the Design Education Workshop, EduTech/NSF, College of Computing, Georgia Institute of Technology.

Hassanain, M. A., Mohammed, M. A., \& Cetin, M. (2012). A Multi-Phase Systematic Framework for Performance Appraisal of Architectural Design Studio Facilities. Facilities, 30, 324-342. http://dx.doi.org/10.1108/02632771211220077

Hellström, T. (2007). The Individual vs. the Group? Individualization and Collectivity among Students in Collaborative Design. International Journal of Technology and Design Education, 17, 305-321.

http://dx.doi.org/10.1007/s10798-006-9004-2

Hu, L. T., \& Bentler, P. M. (1999). Cutoff Criteria for Fit Indexes in Covariance Structure Analysis: Conventional Criteria versus New Alternatives. Structural Equation Modeling: A Multidisciplinary Journal, 6, 1-55. http://dx.doi.org/10.1080/10705519909540118

Ismail, A. M., \& Soliman, M. H. (2010). Integrating Multi-grade Collaborative Learning Pedagogy into Design Studios. ArchNet-IJAR: International Journal of Architectural Research, 4, 201-215.

Kamalipour, H., \& Biglari, S. (2013). Implementing Patterns and Pattern Languages in Collaborative Design Pedagogy: A Case Study in Architectural Education. The IESC2013: The Young Teachers of the Future Discuss Teaching Profession at Maltepe University. Istanbul: Maltepe University.

Kamalipour, H., Houshmandipanah, E., \& Mansouri Kermani, Z. (2013). Collaborative Design Studio in Architectural Education: From Theory to Practice. The IESC2013: The Young Teachers of the Future Discuss Teaching Profession at Maltepe University. Istanbul: Maltepe University.

Klein, M., Sayama, H., Faratin, P., \& Bar-Yam, Y. (2006). The Dynamics of Collaborative Design: Insights from Complex Systems and Negotiation Research. In D. Braha, A. Minai, \& Y. Bar-Yam (Eds.), Complex Engineered Systems: Science Meets Technology (pp. 158-174). Berlin: Springer. http://dx.doi.org/10.1007/3-540-32834-3_8

Kleinsmann, M., Buijs, J., \& Valkenburg, R. (2010). Understanding the Complexity of Knowledge Integration in Collaborative New Product Development Teams: A Case Study. Journal of Engineering and Technology Management, 27, 20-32. http://dx.doi.org/10.1016/j.jengtecman.2010.03.003

Kleinsmann, M., \& Valkenburg, R. (2008). Barriers and Enablers for Creating Shared Understanding in Co-Design Projects. Design Studies, 29, 369-386. http://dx.doi.org/10.1016/j.destud.2008.03.003

Kline, R. B. (2011). Principles and Practice of Structural Equation Modeling. New York: Guilford Press.

Kuhn, S. (2001). Learning from the Architecture Studio: Implications for Project-Based Pedagogy. International Journal of Engineering Education, 17, 349-352.

Kurt, S. (2009). An Analytic Study on the Traditional Studio Environments and the Use of the Constructivist Studio in the Architectural Design Education. Procedia-Social and Behavioral Sciences, 1, 401-408. http://dx.doi.org/10.1016/j.sbspro.2009.01.072 
Kvan, T. (2000). Collaborative Design: What Is It? Automation in Construction, 9, 409-415. http://dx.doi.org/10.1016/S0926-5805(99)00025-4

Kvan, T. (2001). The Pedagogy of Virtual Design Studios. Automation in Construction, 10, 345-353. http://dx.doi.org/10.1016/S0926-5805(00)00051-0

Larsson, A., Törlind, P., Bergström, M., Löfstrand, M., \& Karlsson, L. (2005). Design for Versatility: The Changing Face of Workspaces for Collaborative Design. The 15th International Conference on Engineering Design, Melbourne, 15-18 August 2005, 2275-2289.

Lawson, B. (2004). What Designers Know. Boston, MA: Elsevier/Architectural Press.

Lawson, B. (2006). How Designers Think: The Design Process Demystified (4th ed.). Oxford; Burlington, MA: Elsevier/ Architectural Press.

Lewis, T. (2006). Creativity: A Framework for the Design/Problem Solving Discourse in Technology Education. Journal of Technology Education, 17, 36-53.

Logan, C. (2008). Metaphor and Pedagogy in the Design Practicum. International Journal of Technology and Design Education, 18, 1-17. http://dx.doi.org/10.1007/s10798-006-9009-x

Macpherson, A. (2008). Cooperative Learning Group Activities for College Courses. British Columbia: The Centre for Academic Growth, Kwantlen Polytechnic University.

Martin, W. M., Fruchter, R., Cavallin, H., \& Heylighen, A. (2007). Different by Design. AI EDAM: Artificial Intelligence Engineering Design, Analysis and Manufacturing, 21, 219-225. http://dx.doi.org/10.1017/S0890060407000248

McCallin, A. M., \& McCallin, M. C. H. (2009). Factors Affecting Successful Team Working and Strategies to Facilitate Successful Collaborative Teamwork. New Zealand Journal of Physiotherapy, 37, 62-68.

McPeek, K. T. (2009). Collaborative Design Pedagogy: A Naturalistic Inquiry of Architectural Education. Ph.D. Dissertation, College Station, TX: Texas A\&M University.

Mello, J. A. (1993). Improving Individual Member Accountability in Small Work Group Settings. Journal of Management Education, 17, 253-259. http://dx.doi.org/10.1177/105256299301700210

Millis, B. J., \& Cottell, P. G. (1998). Cooperative Learning for Higher Education Faculty. Phoenix, AZ: Oryx Press.

Ochsner, J. K. (2000). Behind the Mask: A Psychoanalytic Perspective on Interaction in the Design Studio. Journal of Architectural Education, 53, 194-206. http://dx.doi.org/10.1162/104648800564608

Oh, Y., Ishizaki, S., Gross, M. D., \& Yi-Luen Do, E. (2012). A Theoretical Framework of Design Critiquing in Architecture Studios. Design Studies, 34, 302-325. http://dx.doi.org/10.1016/j.destud.2012.08.004

Peeters, M. A. G., van Tuijl, H. F., Reymen, I. M., \& Rutte, C. G. (2007). The Development of a Design Behaviour Questionnaire for Multidisciplinary Teams. Design Studies, 28, 623-643. http://dx.doi.org/10.1016/j.destud.2007.06.004

Pektas, S. T. (2012). The Blended Design Studio: An Appraisal of New Delivery Modes in Design Education. Procedia-Social and Behavioral Sciences, 51, 692-697. http://dx.doi.org/10.1016/j.sbspro.2012.08.226

Pringle, E. (2009). The Artist-Led Pedagogic Process in the Contemporary Art Gallery: Developing a Meaning Making Framework. International Journal of Art \& Design Education, 28, 174-182. http://dx.doi.org/10.1111/j.1476-8070.2009.01604.X

Reimer, Y. J., \& Douglas, S. A. (2003). Teaching HCI Design with the Studio Approach. Computer Science Education, 13, 191-205. http://dx.doi.org/10.1076/csed.13.3.191.14945

Romice, O., \& Uzzell, D. (2005). Community Design Studio: A Collaboration of Architects and Psychologists. Transactions, 2, 73-88. http://dx.doi.org/10.11120/tran.2005.02010073

Russ, R., \& Dickinson, J. (1999). Collaborative Design: “Forming, Storming, and Norming”. Journal of Interior Design, 25, 52-58. http://dx.doi.org/10.1111/j.1939-1668.1999.tb00344.x

Sagun, A., \& Demirkan, H. (2009). On-Line Critiques in Collaborative Design Studio. International Journal of Technology and Design Education, 19, 79-99. http://dx.doi.org/10.1007/s10798-007-9036-2

Santos, J. A. R. (1999). Cronbach's Alpha: A Tool for Assessing the Reliability of Scales. Journal of Extension, 37, 1-5.

Schmitt, G. (1998). A New Collaborative Design Environment for Engineers and Architects. In I. Smith (Ed.), Artificial Intelligence in Structural Engineering: Information Technology for Design, Collaboration, Maintenance, and Monitoring (pp. 384-397). Berlin: Springer. http://dx.doi.org/10.1007/BFb0030464

Schnabel, M. A. (2009). Interplay of Domains. In X. Y. Wang, \& M. A. Schnabel (Eds.), Mixed Reality in Architecture, Design and Construction (pp. 219-226). Dordrecht: Springer.

Schon, D. A. (1995). The Reflective Practitioner: How Professionals Think in Action. England: Bookpoint Ltd.

Schön, D. A. (1984). The Architectural Studio as an Exemplar of Education for Reflection-in-Action. Journal of Architec- 
tural Education, 38, 2-9.

Schön, D. A. (1985). The Design Studio: An Exploration of Its Traditions and Potential. London: RIBA Publications for RIBA Building Industry Trust.

Schön, D. A. (1988). Toward a Marriage of Artistry \& Applied Science in the Architectural Design Studio. Journal of Architectural Education, 41, 4-10.

Sellin, N., \& Keeves, J. P. (1997). Path Analysis with Latent Variables. In J. P. Keeves (Ed.), Educational Research, Methodology, and Measurement: An International Handbook (2nd ed., pp. 633-640). Oxford: Pergamon Press.

Simoff, S. J., \& Maher, M. L. (2000). Analysing Participation in Collaborative Design Environments. Design Studies, 21, 119-144. http://dx.doi.org/10.1016/S0142-694X(99)00043-5

Slavin, R. E. (1995). Cooperative Learning and Intergroup Relations. In J. Banks, \& C. M. Banks (Eds.), Handbook of Research on Multicultural Education (pp. 628-634). New York: Macmillan.

Soliman, M. H., \& Okba, E. M. (2006). Teamwork as a New Sustainable Pedagogy for Teaching Architectural Design. The Ain Shams University International Conference, Cairo, 11-16 September 2006, 181-192.

Strong, D. S., \& Stiver, W. (2005). Engineering Design Competency: Perceived Barriers to Effective Engineering Design Education. The 2nd CDEN International Conference on Design Education, Innovation, and Practice, Kananaskis, 18-20 July 2005.

Summers, J. J., Gorin, J. S., Beretvas, S. N., \& Svinicki, M. D. (2005). Evaluating Collaborative Learning and Community. The Journal of Experimental Education, 73, 165-188. http://dx.doi.org/10.3200/JEXE.73.3.165-188

Tang, H. H., \& Lee, Y. Y. (2008). Using Design Paradigms to Evaluate the Collaborative Design Process of Traditional and Digital Media. In J. S. Gero, \& A. K. Goel (Eds.), Design Computing and Cognition '08 (pp. 439-456). Dordrecht: Springer Science+Business Media B.V.

Tang, J. C. (1991). Findings from Observational Studies of Collaborative Work. International Journal of Man-Machine Studies, 34, 143-160. http://dx.doi.org/10.1016/0020-7373(91)90039-A

Tseng, Y. J., Tzeng, H. L., \& Lin, Y. H. (2005). Collaborative Design Model Planning with a Design Module Formation and Design Task Assignment Model. Journal of the Chinese Institute of Industrial Engineers, 22, 309-317. http://dx.doi.org/10.1080/10170660509509301

Tucker, R., \& Reynolds, C. (2006). The Impact of Teaching Models, Group Structures and Assessment Modes on Cooperative Learning in the Student Design Studio. Journal for Education in the Built Environment, 1, 39-56. http://dx.doi.org/10.11120/jebe.2006.01020039

Ungar, J., \& White, J. (2008). Agile User Centered Design: Enter the Design Studio-A Case Study. The CHI'08 Extended Abstracts on Human Factors in Computing Systems, Florence, 5-10April 2008, 2167-2177.

Valkenburg, R. (2001). Schön Revised: Describing Team Designing with Reflection-in-Action. The DTRS 5, Delft, 18-21 December 2001, 315-329.

Vieira, A. L. (2011). Interactive LISREL in Practice. Heidelberg: Springer. http://dx.doi.org/10.1007/978-3-642-18044-6

Vyas, D., Heylen, D., Nijholt, A., \& Van Der Veer, G. (2009). Collaborative Practices that Support Creativity in Design. In I. Wagner (Ed.), ECSCW 2009 (pp. 151-170). London: Springer. http://dx.doi.org/10.1007/978-1-84882-854-4_9

Wang, W. L., Shih, S. G., \& Chien, S. F. (2010). A “Knowledge Trading Game” for Collaborative Design Learning in an Architectural Design Studio. International Journal of Technology and Design Education, 20, 433-451. http://dx.doi.org/10.1007/s10798-009-9091-y

Webster, H. (2004). The Design Diary: Promoting Reflective Practice in the Design Studio. Architectural Design: Monitoring Architectural Design. EAAE Transactions on Architectural Education, 24, 343-356.

Yilmaz, S., Seifert, C. M., \& Gonzalez, R. (2010). Cognitive Heuristics in Design: Instructional Strategies to Increase Creativity in Idea Generation. Artificial Intelligence for Engineering Design, Analysis and Manufacturing, 24, 335-355. http://dx.doi.org/10.1017/S0890060410000235

Yin, Y., Qin, S., \& Holland, R. (2011). Development of a Design Performance Measurement Matrix for Improving Collaborative Design during a Design Process. International Journal of Productivity and Performance Management, 60, 152184. http://dx.doi.org/10.1108/17410401111101485 